\title{
In silico screening of herbal and nanoparticle lead compounds for effectivity against H5N1, H1N1 neuraminidase and telomerase
}

Sayak Ganguli, Manjita Mazumder, Protip Basu, Paushali Roy, Sayani Mitra, Abhijit Datta

From The Eighth Asia Pacific Bioinformatics Conference (APBC 2010)

Bangalore, India. 18-21 January 2010

\begin{abstract}
This article has been withdrawn from the public domain because of significant plagiarism. In the light of this situation, BioMed Central regrets that this article is no longer available. The authors apologise to all affected parties for the inconvenience.
\end{abstract}

Published: 18 January 2010

doi:10.1186/1471-2105-11-S1-S13

Cite this article as: Ganguli et al: In silico screening of herbal and

nanoparticle lead compounds for effectivity against H5N1, H1N1

neuraminidase and telomerase. BMC Bioinformatics 2010 11(Suppl 1):S13.

* Correspondence: sayakbif@yahoo.com

DBT-Centre for Bioinformatics, Presidency College, Kolkata, India

Submit your next manuscript to BioMed Central and take full advantage of:

- Convenient online submission

- Thorough peer review

- No space constraints or color figure charges

- Immediate publication on acceptance

- Inclusion in PubMed, CAS, Scopus and Google Scholar

- Research which is freely available for redistribution 